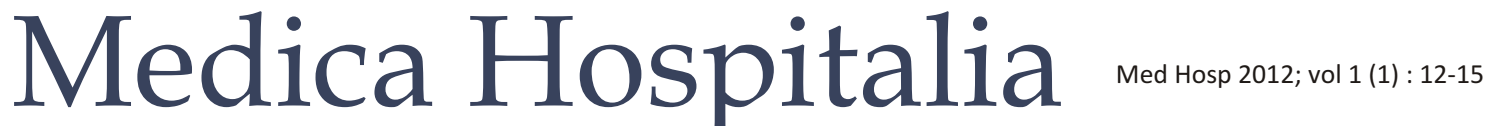

Original Article

\section{Pengaruh Pemberian Ketamin Dosis 0,1, 0,2 dan 0,4 mg/kgBB terhadap Kadar Nitric Oxide Makrofag Mencit Balb/c yang Diberi Lipopolisakarida}

\author{
Sulung Prasetyo $\mathrm{H}^{*}$, Witjaksono* \\ *Bagian/SMF Anestesi Fakultas Kedokteran Universitas Diponegoro/RSUP Dr. Kariadi Semarang
}

\begin{abstract}
Abstrak
Latar belakang : NO (nitric oxide) memiliki peranan penting dalam patogenesis terjadinya hipotensi sistemik pada syok septik. Paparan endotoksin akan menyebabkan peningkatan aktivitas NOS dan pelepasan NO. Sitokin proinflamasi merupakan mediator inflamasi yang berpengaruh dalam peningkatan aktivitas NOS dan pelepasan NO. Ketamin merupakan obat anestesi yang seringkali digunakan untuk penderita sepsis, diduga menekan produksi sitokin proinflamasi akibat paparan endotoksin serta menghambat aktivasi NF-kB, sehingga pembentukan NO dapat dihambat. Tujuan penelitian adalah mengetahui pengaruh pemberian ketamin dosis 0,1;0,2 dan 0,4 $\mathrm{mg} / \mathrm{kg}$ inravena terhadap kadar NO mencit yang diberi lipopolisakarida intraperitoneal.

Metode : merupakan penelitian eksperimental laboratorik dengan desain randomized post test only controlled group pada 20 ekor mencit Balb/c yang disuntik lipoplisakarida intraperitoneal dan Ketamin dosis 0,$1 ; 0,2$ dan $0,4 \mathrm{mg} / \mathrm{kg}$ intravena. Mencit dibagi menjadi 4 kelompok secara random, yaitu kelompok P1 sebagai kontrol, kelompok P2 yang mendapat ketamin $0,1 \mathrm{mg} / \mathrm{kg}$, kelompok P3 yang mendapat ketamin 0,2 mg/kg, dan kelompok P4 yang mendapat ketamin dosis $0,4 \mathrm{mg} / \mathrm{kg}$. Pemeriksaan NO diambil dari kultur makrofag intraperitoneal setelah 6 jam pemberian ketamin. Hasil dinilai dengan uji statistik parametrik ANOVA dan dilanjutkan Post hoc dengan derajat kemaknaan $p<0,05$.

Hasil : terdapat perbedaan kadar NO yang signifikan pada kelompok P2,P3 dan P4 dibanding P1 dengan $p<0,001, \mathrm{P} 2$ dibanding $\mathrm{P} 3$ dengan $p=0,015$ serta $\mathrm{P} 2$ dibanding $\mathrm{P} 4$ dengan $p=0,002$. Sedangkan antara kelompok P3 dibanding P4 tidak didapatkan perbedaan yang bermakna dengan $p=0,402$.

Simpulan : ketamin dapat menurunkan kadar NO makrofag intraperitoneal pada mencit yang terpapar LPS secara signifikan. Ketamin dosis $0,2 \mathrm{mg} / \mathrm{kg}$ intravena merupakan dosis optimal untuk menurunkan kadar NO makrofag intraperitoneal.
\end{abstract}

Kata kunci : lipopolisakarida, ketamin, nitric oxide (NO).

\author{
The effect of ketamine $0.1,0.2$ and $0.4 \mathrm{mg} / \mathrm{kg}$ \\ doses on the nitric oxide level of \\ Balb/c mice macrofag following \\ Lipopolysaccharide injection
}

\begin{abstract}
Background : Nitric oxide (NO) has a potential rule in pathogenesis of systemic hypotension in septic shock. Endotoxin has been shown to increase the activity of the iNOS enzyme and NO release. Proinflamatory cytokines are inflammatory mediators which implicated in the induction and anion of iNOS and NO release also. Ketamine is anesthetic agent and commonly used for patients. This agent suppressed endotoxin induced proinflamatory cytokines production and blockade the activation of NF-kB, so the NO production can be inhibited. Objective of the study was to know the effect of Ketamine 0,$1 ; 0,2$ and $0,4 \mathrm{mg} / \mathrm{kg}$ intravenous on intraperitoneal NO level of Balb/c mice injected with lipopolysaccharide intraperitoneally.

Methods : a randomized post test only controlled group laboratoric experimental study on animal,20 male Balb/c mice divided into 4 groups, PI as the control group. All mice were injected popolysaccharide $20 \mathrm{mg} / \mathrm{kg}$ intraperitoneally and 6 hours later were injected by ketamine 0,$1 ; 0,2$; and $0,4 \mathrm{mg} / \mathrm{kg}$ intravenously in group P2, P3, and P4 respectively. NO was taken from peritomeal macrophage culture and observed by Grease method. The data were analyzed by ANOVA and post hoc statistical assay, with reliability $p<0,05$.

Results : There were significant differences in NO level between $\mathrm{P} 2, \mathrm{P} 3$ and P4 vs $\mathrm{P} 1(p<0,001), \mathrm{P} 2$ vs P3 $(p=0,015)$ and P2 vs P4 $(p=0,002)$. But there was no significant difference between $p 3$ vs P4 $(p=0,402)$.

Conclusion : Ketamine is effective for decreasing nitric oxide level in mice intraperitoneal macrophage which induced by LPS. Ketamine $0,2 \mathrm{mg} / \mathrm{kg}$ is the optimum dose for decreasing intraperitoneal nitric oxide level.
\end{abstract}

Keywords: ketamine, lipopolysaccharide, nitric oxide. 


\section{PENDAHULUAN}

Angka mortalitas yang masih tinggi menyebabkan sepsis sebagai masalah kesehatan dunia. Patofisiologi syok septik sudah banyak diketahui tetapi terapi masih terbatas dan mortalitas pasien masih tinggi. Dari datadata penelitian terapi inovatif da clinical trial belum menghasilkan perbaikan yang signifikan dalam 40 tahun terakhir. ${ }^{1,2}$ Penyebab terbesar sepsis adalah bakteri gram negatif dengan persentase hampir 60\%. Di Amerika Serikat sekitar 20-60\% angka kejadian bakteriemia disebabkan oleh bakteri gram negatif dan rata-rata 20\% berkembang menjadi sepsis dengan angka kematian $40 \%$ tiap tahunnya. Produk yang berperan besar terhadap sepsis adalah lipopolisakarida (LPS) atau endotoksin glikoprotein kompleks yang merupakan komponen utama membran terluar bakteri gram negatif dan merupakan salah satu faktor patogenik pada sepsis dan penyebab sepsis terbanyak. ${ }^{3,4,12}$

Respons sistemik terhadap sepsis akibat LPS akan menyebabkan adanya produksi mediator-mediator inflamasi atau sitokin proinflamasi yaitu tumor necrosis factor (TNF-a), interleukin (IL- $\beta$ ) serta interferon gamma (IFN- $\gamma$ ) yang akan meningkatkan ekspresi nitric oxide (NO) dalam jumlah besar melalui peningkatan aktivasi iNOS (inducible isoform Nitric oxide sintetase). 5,12,14-15

Produksi NO yang meningkat pada sepsis menyebabkan perubahan fungsi kardiovaskuler seperti terjadinya hipotensi sistemik akibat hipokontraktilitas pembuluh darah serta depresi otot jantung sehingga terjadi kegagalan sirkulasi yang mengarah pada kegagalan organ atau disebut juga multiple organ system failure (MOSF).$^{6-8,16-17}$

Pengelolaan anestesi pada pasien sepsis merupakan suatu hal yang sangat penting apabila tindakan operatif metupakan salah satu upaya dalam mengatasi sumber infeksi yang menyebabkan terjadinya sepsis. Ketamin suatu antagonis dari reseptor Nmethyl-Daspartat, sering digunakan karena mempunyai efek sedasi dan analgesi kuat. Ketamin adalah obat anestesi yang mempunyai efek stimulasi terhadap kardiovaskuler, meningkatkan cardiac output dan systemic vascular resistance melalui stimulasi pada sistem saraf simpatis yang menghasilkan pelepasan katekolamin. ${ }^{16,17}$ Dalam penelitian Shimoka et al (1996) menyebutkan bahwa pemberian ketamin $150 \mathrm{Mm}$ secara signifikan menekan produksi sitokin proinflamasi dan NO pada kultur makrofag yang telah diberi endotoksin. ${ }^{9-11}$

Pada penelitian ini paparan LPS dilakukan terhadap mencit dengan penyuntikan intraperitoneal karena pada intraperitoneal terdapat banyak makrofag yang merupakan tipe sel spesifik untuk NOS yang dipicu oleh LPS. Dosis yang diberikan sesuai dengan dosis analgesi dan induksi. ${ }^{11-14}$

Tujuan penelitian ini adalah membuktikan efek pemberian ketamin 0,1, 0,2 dan 0,4 $\mathrm{mg} / \mathrm{kgBB}$ intravena pada mencit yang disuntik LPS intraperitoneal terhadap penurunan kadar NO makrofag intraperitoneal dan menilai adanya perbedaan penurunan kadar NO makrofag intraperitoneal antara mencit yang terpapar LPS yang mendapat ketamin 0,1, 0,2 dan 0,4 mg/ kgBB dengan yang tidak mendapat ketamin intravena. Hasil penelitian ini dapat dijadikan sumbangan teori dalam upaya menerangkan pengaruh pemberian ketamin terhadap kejadian SIRS/sepsis. Mengetahui efektifitas pemberian ketamin pada kondisi sepsis. Penelitian ini dapat menjadi landasan untuk penelitian lebih lanjut.

\section{METODE}

Penelitian ini termasuk eksperimental murni uji praklinis dengan desain randomized post test only controlled group dengan tujuan mencari pengaruh pemberian ketamin intravena pada mencit yang diberi lipopolisakarida intraperitoneal terhadap kadar NO makrofag intraperitoneal.

Kelompok perlakuan dibagi menjadi 4 yaitu kelompok kontrol (P1), Perlakuan 1 (P2), Perlakuan 2 (P3), Perlakuan 3 (P4). Pembagian kelompok perlakuan: P1 : Kelompok kontrol; mencit yang disuntik LPS intraperitoneal P2 : Kelompok perlakuan 1, mencit yang disuntik LPS intraperitoneal, mendapat Ketamin $0,5 \mathrm{mg} / \mathrm{kgBB}$ intravena P3 : Kelompok perlakuan 2, mencit yang disuntik LPS intraperitoneal, mendapat Ketamin $1 \mathrm{mg} / \mathrm{kgBB}$ intravena $\mathrm{P} 4$ : Kelompok perlakuan 3 , mencit yang disuntik LPS intraperitoneal, mendapat Ketamin $2 \mathrm{mg} / \mathrm{kgBB}$ intravena.

Dosis obat yang diberikan disetarakan dengan dosis pada manusia dengan berat badan $70 \mathrm{~kg}$ dikalikan konstanta uji terapi pada hewan coba (mencit) yaitu 0,0026 . Dosis yang diberikan pada masing-masing kelompok: $0,5 \mathrm{mg} / \mathrm{kgBB} \rightarrow 0,5 \mathrm{mg} / \mathrm{kgBB} \times 70 \mathrm{~kg} \times 0,0026$ $=0,1 \mathrm{mg}$. Populasi penelitian adalah mencit jantan strain Balb/c. Sampel diambil secara acak tersamar ganda yang memenuhi kriteria inklusi dan eksklusi dengan waktu penelitian 30 hari. Mencit dipelihara di laboratorium Biologi Universitas Semarang. Penelitian dilakukan di Laboratorium CEBIOR FK UNDIP Rumah Sakit Dr. Kariadi Semarang. Kriteria inklusi adalah mencit Balb/c jantan, umur 8-10 minggu, berat badan 20 - 30 gram, tidak ada kelainan anatomis sehat dan aktif selama masa adaptasi. Kriteria eksklusi adalah mencit sakit selama masa adaptasi 7 hari (gerakan tidak aktif) atau mati selama perlakuan berlangsung.

Besar sampel sebanyak 20 mencit berdasarkan Research Guidelines For Evalution The safety and Efficiacy of Herbal Medicines dari WHO, kemudian sampel dikelompokkan secara random menjadi 4 kelompok yaitu kelompok P1 : 5 mencit; kelompok P2 : 5 mencit; kelompok P3:5 mencit dan kelompok P4:5 mencit.

Masing-masing kelompok dilakukan pemeriksaan kadar NO supernatan kultur macrofag intraperitoneal. 
Setelah data terkumpul dilakukan data cleaning, coding dan tabulasi. Data dikumpulkan dan diolah dengan menggunakan program komputer SPSS 13.0 for windows dan analisa data meliputi analisis deskriptif dalam bentuk rerata, standard deviation dan grafik. Pada variabel bebas didapatkan skala pengukuran nominal yaitu diberi ketamin dan tidak diberi ketamin sedang pada variabel terikat untuk kadar NO didapatkan skala pengukuran rasio.

Dilakukan uji normalitas dengan Shapiro-Wilk test untuk mengetahui sebaran data. Untuk distribusi data normal, dilakukan uji beda dengan ANOVA dilanjutkan dengan uji post hoc. Untuk data tidak terdistribusi normal, menggunakan uji beda Kruskal Wallis dilanjutkan dengan Mann Whitney untuk melihat beda antara kelompok P2, P3, dan P4 dengan kelompok P1.

\section{HASIL}

Hasil dari pengukuran kadar nitrit oksida dapat dilihat pada tabel1.

Hasil pengamatan rerata kadar NO makrofag intraperitoneal pada keempat kelompok menunjukkan kadar NO yang berbeda yaitu pada kelompok perlakuan 3 (P4) menunjukkan penurunan kadar NO yang paling banyak dibandingkan kelompok kontrol (P1).

Uji normalitas menggunakan tehnik Shapiro-Wilk didapatkan bahwa kadar NO makrofag intraperitoneal pada kelompok kontrol (P1), kelompok perlakuan 1 (P2),

\begin{tabular}{|ccccc|}
\hline \multicolumn{5}{|l}{$\begin{array}{l}\text { TABEL 1 } \\
\text { Kadar nitrit oksida pada kelompok kontrol } \\
\text { dan kelompok perlakuan }(\boldsymbol{\mu M})\end{array}$} \\
\hline Sampel & $\mathbf{P 1}$ & $\mathbf{P 2}$ & $\mathbf{P 3}$ & $\mathbf{P 4}$ \\
\hline 1 & 41,12 & 13,76 & 11,82 & 8,82 \\
2 & 42,33 & 16,53 & 12,94 & 10,17 \\
3 & 41,70 & 13,62 & 14,20 & 10,80 \\
4 & 44,66 & 15,07 & 10,37 & 10,13 \\
5 & 46,60 & 15,46 & 9,11 & 13,47 \\
Rerata & 42,1 & 14,7 & 11,2 & 10,9 \\
\hline
\end{tabular}

kelompok perlakuan 2 (P3) dan kelompok perlakuan 3 (P4) terdistribusi normal dengan nilai $p>0,05$.

Uji beda dilakukan dengan menggunakan ANOVA dan dilanjutkan dengan uji hipotesis. Didapatkan hasil uji varian data $p>0,05$ maka varian data dianggap normal. Sehingga tabel uji ANOVA adalah valid, dengan interpretasi bahwa paling tidak didapatkan perbedaan bermakna pada dua kelompok, kemudian dilanjutkan dengan uji Post Hoc dengan LSD seperti tampak pada tabel 2.

Dari tabel 2 dapat dilihat bahwa kadar NO makrofag intraperitoneal pada kelompok P1 (kontrol) dibanding dengan masing-masing kelompok perlakuan (P1, P2, P3) terdapat perbedaan bermakna dengan nilai $\mathrm{P}<0,001$. Terdapat perbedaan yang bermakna antara kadar NO makrofag intraperitoneal pada kelompok perlakuan P2 dibandingkan kelompok perlakuan P3 $(p=0,015)$ dan kelompok perlakuan P2 dibandingkan kelompok perlakuan P4 $(p=0,002)$, sedangkan kadar NO makrofag intraperitoneal pada kelompok perlakuan P3 dibandingkan kelompok perlakuan $\mathrm{P} 4$ berbeda tidak bermakna dengan nilai $p=0,402(p>0,05)$.

\section{PEMBAHASAN}

Endotoksin atau LPS adalah suatu komponen membran luar dari bakteri gram negatif yang dapat menginduksi sepsis. Patofisiologi sepsis sudah banyak diketahui tetapi terapi masih terbatas dan mortalitasnya masih tinggi. Efek paparan LPS menyebabkan pelepasan beberapa sitokin (TNF- $\alpha$, NFkB, IL-1, IL-8) sebagai media pertahanan tubuh terhadap benda asing yang memiliki dampak positif dan negatif. Pada sepsis terjadi pelepasan sitokin proinflamasi seperti TNF-a, IL-113, IL-8 yang berhubungan dengan kerusakan endotel dan jaringan yang nantinya akan menyebabkan hipotensi sistemik, hiporeakttif vaskuler, dan depresi miokard. ${ }^{5}$

NO adalah molekul biologi yang dihasilkan oleh berbagai jenis sel, mempunyai pengaruh yang baik dan juga buruk terhadap ditingkat pembuluh darah dan seluler. NO merupakan kunci penting pada patogenesis sepsis. Pada pemberian LPS akan merangsang pelepasan mediator proinflamasi seperti TNF-a, serta IL-1 yang akan menginduksi aktivasi NOS dalam memproduksi NO. Makrofag merupakan komponen penting dari

TABEL 2

Uji Post Hoc dengan LSD

P2 P3 $\quad$ P4

ketamin 0,1 kg/mgBB ketamin $0,2 \mathrm{~kg} / \mathrm{mgBB}$

$p<0,001$

$\mathrm{P}=0,015$ ketamin $0,4 \mathrm{~kg} / \mathrm{mgBB}$

$p<0,001$

$\mathrm{P}=0,002$

$P=0,402$
P1 Kontrol

$\mathrm{P} 2$ ketamin 0,1 mg/kgBB

P3 ketamin 0,2 mg/kgBB $p<0,001$ 
respons inflamasi terhadap injuri jaringan dan merupakan tipe sel untuk pemeriksaan kadar NO terutama NOS?

Hasil pengamatan dapat dilihat bahwa terdapat penurunan kadar NO makrofag intraperitoneal yang bermakna pada pemberian ketamin baik pada dosis $0,1 \mathrm{mg} / \mathrm{kgBB}, 0,2 \mathrm{mg} / \mathrm{kgBB}$ maupun pada pemberian ketamin dosis $0,4 \mathrm{mg} / \mathrm{kgBB}$ dibandingkan dengan kelompok yang tidak diberi ketamin. Dan penelitian ini juga didapatkan pemberian ketamin dosis $0,4 \mathrm{mg} / \mathrm{kgBB}$ menurunkan kadar NO makrofag intraperitoneal yang paling besar dibanding kelompok perlakuan yang lain apabila dilihat dari rerata kadar NO.

Pada penelitian ini didapatkan hasil bahwa ketamin pada dosis $0,4 \mathrm{mg} / \mathrm{kgBB}$ pada mencit yang setara dengan pemberian dosis ketamin $2 \mathrm{mg} / \mathrm{kgBB}$ pada manusia tidak menurunkan kadar NO secara signifikan dibandingkan dengan ketamin dosis $0,2 \mathrm{mg} / \mathrm{kgBB}$ pada mencit yang setara dengan pemberian ketamin $1 \mathrm{mg} / \mathrm{kgBB}$ pada manusia. Penelitian yang telah dilakukan mendapatkan bahwa ketamin dosis 0,1, 0,2 dan $0,4 \mathrm{mg} / \mathrm{kgBB}$ pada mencit semuanya efektif dalam menekan produksi NO.

\section{SIMPULAN}

Pemberian ketamin dosis $0,1 \mathrm{mg} / \mathrm{kgBB}, 0,2 \mathrm{mg} / \mathrm{kgBB}$ dan $0,4 \mathrm{mg} / \mathrm{kgBB}$ intravena pada mencit menunjukkan perbedaan bermakna pada kadar NO makrofag intraperitoneal dibanding kontrol.

Pemberian ketamin dosis $0,2 \mathrm{mg} / \mathrm{kgBB}$ intravena merupakan dosis optimal untuk menurunkan kadar $\mathrm{NO}$ makrofag intraperitoneal. Pemberian ketamin $0,1 \mathrm{mg} / \mathrm{kgBB}$ yang setara dengan $0,5 \mathrm{mg} / \mathrm{kgBB}$ pada manusia dan ketamin $0,2 \mathrm{mg} / \mathrm{kgBB}$ pada mencit yang setara dengan $1 \mathrm{mg} / \mathrm{kgBB}$ pada manusia dapat digunakan pada kondisi sepsis oleh karena dapat menurunkan kadar NO makrofag intraperitoneal.

\section{DAFTAR PUSTAKA}

1. Oberholzer C, Oberholzer A, Clare-salzler M, Moldawer LL. Apoptosis in sepsis: a new target for therapeutic exploration. The FASEB Journal 2001;15:879-92.

2. RL Paterson, NR Webster.Sepsis and the Systemic inflammatory Responsse Syndrome. R.Coll.Surg.Edinb 2000;178-82.

3. Hotchkiss SR, Karl EI. The Pathophysiology and Treatment of Sepsis.2003;348:138-50.

4. Barash G, Paul MD. Septic shock. Clinical Anesthesia. $4^{\text {th }}$ ed. Lippincott Williams \&Wilkins Publishers 2001; p1069-76

5. Karl IE. Pathogenesis of sepsis and multiorgan dysfunction. J Cell Biochem 1992;267:10931-44.

6. Hermawan AG. SIRS dan Sepsis (Imunologi, Diagnosis, Penatalaksanaan). Sebelas Maret University Press. Edisi pertama. Mei 2006.

7. Vincent JL, Zhang J, Szabo C, Preiser JC. Effect of Nitric Oxide in Septic Shock. Am J Respir Crit Care Med 2000;16(1):1781-85.

8. Moncada S, Higgs A. The L-Arginine-Nitric oxide pathway. NEJM1993;329:2002-12.

9. Danielle P K, Bull S, Duk P V, Gremmels J, Hellebrekers L. Ketamin inhibits LPS-induce Tumor Necrosis Faktor-alpha and Interleukin-6 in an Equine Macrophag Cell Line. Section Anesthesiologi and Intensive Care, Utrecht University; 2005: 257-62.

10. Shimaoka M, Iida A, Ohara, Taenaka N, Mashimoto T, Honda T. Ketamine inhibisi nitric oxide production in mouse-activated macrophage-like cell. British journal of Anesthesia 1996; 77: 23842

11. Yuan C, Cou C, Shung C, Ding Y, Yen M. Ketamine inhibits nitric oxide synthase in lipopolysaccharide-treated rat alveolar macrophages. Can J Anesthesia 2001; 44(9):989-95

12. Kawasaki C, Kawasaki T, Ogata M, Nandate K, Shigematsu A. Ketamine isomers supress supernatigen-induced proinflamatory cytokine production in human whole blood. Can J Anesthesia $2001 ; 48(8): 819-23$

13. Arnold S, Kristof, Peter G, Victor L, Sabah AH. Role of Inducible Nitric Oxide Synthase in Endotoxin-induced Acute Lung Injury. Am. J. Respir. Crit. Care Med 1998;158(6):1883-89.

14. Abbas AK. Basic Immunology: Functions and disorders of the immune system. $2^{\text {nd }}$ ed. Philadelphia: Elsevier Saunders Companies.2007

15. Wright G, Singh IS, Hasday JD, Farrancel IK, Hall G, Cross AS, and Rogers TB. Endotoxin stress-response in cardiomyocytes: NF-KB activation and tumor necrosis factor-a expression. Am J Physiol Heart CircPhysiol2002;282:872-79

16. Morgan GE, Mikahil MS, Murray MJ, Larson CP. Nonvolatile anesthetic agent. In : Morgan GE, Mikhail MS, Murray MJ, Larson CP. Clinical anesthesiology $4^{\text {th }}$ ed.New York : Lange Medical Books/McGraw-Hill Medical Publishing Edition; 2006: 164

17. Stoelting, Hiller. Pharmacology and Physiology in anesthetic practice. $4^{\text {th }}$ Ed. Philadelphia: Williams and Wilkins; 2006:p14154 